
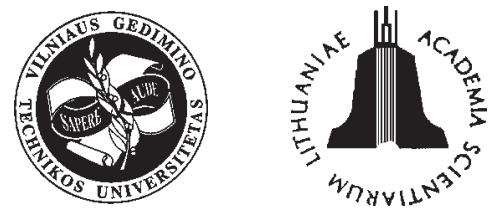

\title{
FEM STABILITY ANALYSIS OF TAPERED BEAM-COLUMNS
}

\author{
Vaidotas Šapalas ${ }^{1}$, Michail Samofalov ${ }^{2}$, Viačeslavas Šaraškinas ${ }^{3}$ \\ Vilnius Gediminas Technical University, Sauletekio al. 11, LT-10223 Vilnius, Lithuania. \\ E-mail:11vdt@st.vtu.lt; ${ }^{2} m s @ f m . v t u . l t ;{ }^{3}$ slavik@st.vtu.lt
}

Received 15 March 2004; accepted 29 July 2005

\begin{abstract}
This paper deals with a theoretical and a numerical analysis of tapered beam-columns subjected to a bending moment and an axial force. A standard FEM code COSMOS/M has been used for a numerical estimation of a critical load multiplier. It has been assumed that the critical force of an axially loaded tapered column could be calculated in an analogous way as for uniform member just with an additional correction factor $\alpha_{n}$. Similarly, a critical bending moment of the tapered column subjected to a pure bending could be determined by using a correction factor $\alpha_{m}$. A large number of simulations carried out within a wide range of the ratios of second moments of area allowed to determine the proper values of theses two factors. For practical engineers, solution of such kind of problems can be easier when an equivalent cross-sectional height $h_{t r}$ is used.
\end{abstract}

Keywords: thin-walled beam, space stability, tapered columns, finite element method, natural experiment, warping.

\section{Introduction}

During the last years, light steel structures have been extensively used as being the most effective in practical application. The main advantages of such kind of structures are the effective usage of materials and quick erection as well as their good service characteristics. Over the past two decades, solution of the buildings with tapered frames, manufactured from high-tensile steel, have become a standard. The use of automatic welding techniques minimises the cost of such tapered members. Their contours are quite close to the bending moment diagram, so the bearing capacity of cross-sections is effectively utilised. With this type of frames the web depth-to-thickness ratio can exceed 200. There is no need of many additional stiffeners in this case.

Analysis of such a kind of frames is rather complicated and not widely investigated. For example, there are no recommendations in European design codes [1] how to calculate such structural members. A thin-walled column subjected to an axial force and bending moment can lose stability in lateral torsional buckling mode.

Stability of axially loaded tapered columns was investigated in [2-4], authors of which proposed to calculate tapered columns as uniform members, using additional factors.

It is obvious that results of buckling analysis for a tapered column under the combination of an axial force and a bending moment cannot be obtained just by adding the solutions obtained for those loads acting separately because this dependency is non-linear. A stability problem of tapered columns subjected to combinations of load factors was numerically investigated in [5]. There a possibility to solve stability problem depended on wellknown separate buckling shape modes as well as on corresponding load factors of an axial force and bending moment was presented which provided the accuracy satisfactory for practical applications. As one can see from this review, there are no commonly accepted methods for an analysis of tapered columns in the literature.

\section{Stability theory of thin-walled beam-columns}

\subsection{Concepts of the problem}

The first solutions of the buckling problem for structural members were considered using the classical theory of thin-walled beams S. P. Timoshenko [6], V. Z. Vlasov [7], F. Bleich [8], A. N. Dinnik, [9] etc. Generally, the stability problem of thin-walled beams is complicated due to warping phenomena of their cross-sections [3, 7]. For a more easy analysis of this problem some researchers have been trying to give an effective tool by using analytical and numerical methods $[10,11]$.

More general cases of the problem are considered with an element with the curvilinear longitudinal axis [12], with analysis of stability of plates with additional stiffeners $[13,14]$, with calculation of stability of beam-columns with an additional number of degrees of freedoms (DOF) [15], etc. 
One of the first wide-known and popular in the practical usage publications in field of stability analysis applying the finite element methodology (evaluating warping phenomena of a cross-section) and using the classical theory of thin-walled beam-columns and shells belongs to R.J. Plank and W.H. Wittrick [16], Y.K. Cheung [17], P.O. Friberg [18], N.W. Murray [19], etc. A fundamental paper in the stability analysis, using one-dimensional finite elements with the warping effect, was published by Y.-B. Yang and W. McGuire [20] in 1986. Various authors [21-24], applying different assumptions, have shown some possibilities to make the geometric nonlinear stiffness matrices for solving of such a problem.

On the other hand, some practical methods for stability analysis of the beam-columns, based on finite element discretisation idea, have been evaluated [25-27].

\subsection{Axially loaded structural member}

As an example, the stability problem of an industrial column with a variable cross-section is considered. The axially loaded slender tapered column looses its initial stability shape, when it is subjected to an external force $N$, which exceeded the critical value $N_{c r}$ :

$$
N>N_{c r} .
$$

The flexibility differential equation of the axially loaded beam-column with longitudinal axis $O x$ (Fig 1a) may be expressed as:

$$
\frac{d^{2} v(x)}{d x^{2}}+\frac{N}{E I} v(x)=0,
$$

or, in the most popular manner, as:

$$
E I \cdot v^{\prime \prime}(x)+N \cdot v(x)=0 .
$$

Here $v$ is a transversal displacement, EI stands for a minimal rigidity of flexibility for the bent member.

For a uniform cross-section of the column (traditionally - constant in the longitudinal direction), results of solution of the equation (2) obtained by L. Euler:

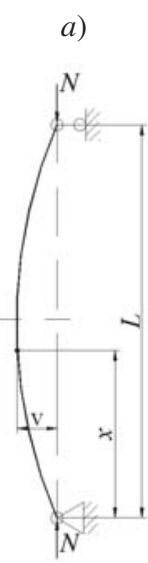

b)

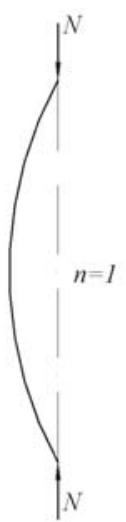

c)

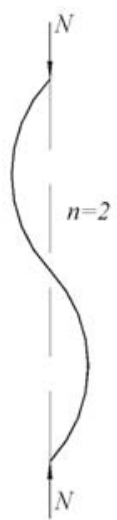

d)

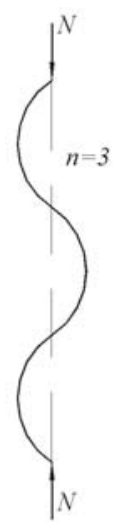

Fig 1. Axially loaded pin column (a) and its buckling shape modes: the first (b); the second (c); the third (d)

$$
N_{c r}=\left(\frac{n \pi}{L}\right)^{2} E I_{\text {min }},
$$

where $n$ marks a theoretical number of a buckling shape mode (Fig 1) and $L$ is the column length.

In case of a tapered column (with a variable crosssection) the formula (3) depends on the variable in longitudinal direction stiffness factor $E I(x)$. Therefore, the law of distribution of the second moment of area may be presented as:

$$
I(x)=I_{2}\left[1-\left(1-k^{2 m}\right) \frac{2 x}{L}\right],
$$

here $x$ is a distance from the column end, named by symbol "1", to the considered cross-section (Fig 2). The other end of the column is marked by number "2". The most valuable factor in expression (4) is described as [9]:

$$
k^{2 m}=\frac{I_{y 1}}{I_{y 2}},
$$

where $m$ is a factor of the longitudinal distribution of the second moment of area. This factor can be changed as $m=1,2,3$ or 4 , depending on a cross-sectional type.

A differential equation of the tapered column was proposed by A.N. Dinnik [8]:

$$
E I\left(\frac{x}{d}\right)^{m} \cdot v^{\prime \prime}(x)+N \cdot v(x)=0,
$$

where $d$ is a distance from the bigger edge of a column section up to a fictional point, the second moment of area of the column in which tends to zero.

In such case, the expression of the above-mentioned equation (6) may be presented as:

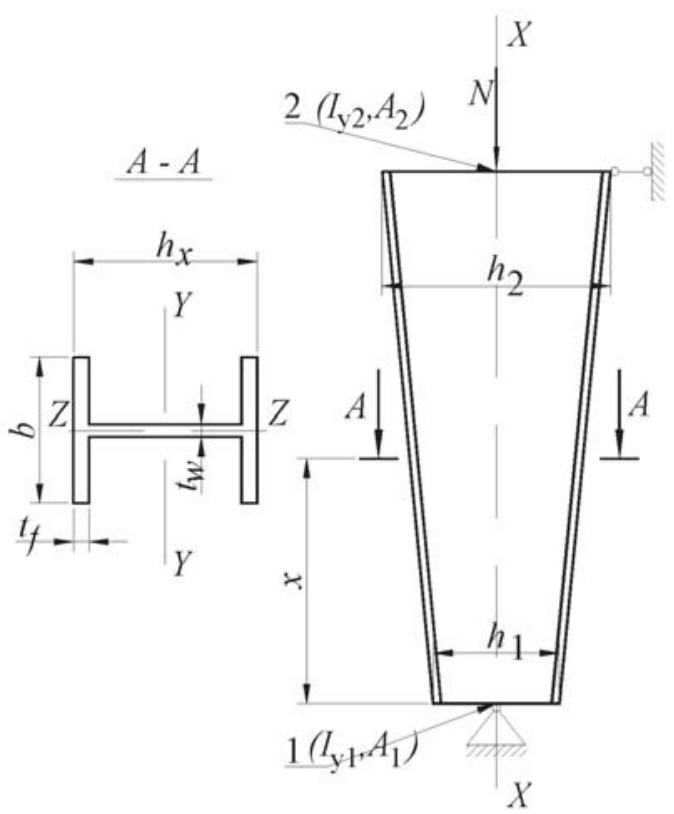

Fig 2. Axially loaded tapered column and its cross-section 


$$
N_{c r t r}=\alpha_{n}\left(\frac{\pi}{\mu_{y} L}\right)^{2} E I_{y 2},
$$

where $\alpha_{n}$ is an algebraic factor, depending on variability of the second moment of area.

\subsection{Case of pure bending}

The next case, when each of the cross-sections of the slender tapered column is subjected to bending moment only. Such a case in Vlasov's theory of thin-walled beams [7] is investigated as pure bending, so a value of critical bending moment can be solved for a uniform beam with an $I$-section, according to European design code [1], as:

$$
M_{c r}=\sqrt{\left(\left(\frac{\pi}{\mu_{z} L}\right)^{2} E I_{z}\right) \cdot\left(G I_{t}+\left(\frac{\pi}{\mu_{\omega} L}\right) E I_{\omega}\right)},
$$

where $E I_{z}, G I_{t}$ and $E I_{\omega}$ are corresponding stiffness: flexibility about the minor axis; torsional from the classical B. Saint-Venant's theory; warping. The factors $\mu_{z} L$ and $\mu_{\omega} L$ are described as the effective lengths of the considered beam for flexibility and warping.

The critical value of the bending moment for the tapered column can be easily defined by formula (8), using an additional parameter:

$$
M_{c r t r}=\alpha_{m}\left(\frac{\pi}{\mu_{z} L}\right) \sqrt{E I_{z}\left(G I_{t}+\left(\frac{\pi}{\mu_{\omega} L}\right) E I_{\omega}\right)},
$$

where $\alpha_{m}$ is a factor, depending on the longitudinal distribution of the second cross-sectional moment of area $I_{y}(x)$. In case of a tapered column, the following crosssectional parameters are also varied: warping constant $I_{\omega}(x)$; torsional moment of inertia $I_{t}(x)$.

\section{Stability analysis by the finite element method}

\subsection{Concepts of the stability analysis}

The FEM has long been recognised as one of the most effective techniques for analysing common thinwalled structures and their structural members under arbitrary loading and boundary conditions. Exact analytical solutions for the stability problem are well-known and popular for particular cases of separate loading (3) and (8).

The most general critical condition, at which stability of a structure impends, is obtained considering the second variation of the total potential energy. By applying a standard finite element approach, the system of geometrically non-linear equations can be symbolically written in the following form:

$$
\mathbf{A}(\mathbf{F}, \mathbf{u})=\mathbf{0},
$$

where $\mathbf{A}$ is a differential operator, in the most general case non-linear in load $\mathbf{F}$ and displacement $\mathbf{u}$. This equation can be presented by an incremental form:

$$
\left(\left[\mathbf{K}_{\text {lin }}\right]+\left[\mathbf{K}_{\sigma}\right]+\left[\mathbf{K}_{u}\right]\right) \Delta \mathbf{u}=\Delta \mathbf{F},
$$

where $\left[\mathbf{K}_{\text {lin }}\right]$ is a linear elastic stiffness matrix, $\left[\mathbf{K}_{\sigma}\right]$ is an initial stress stiffness matrix, $\left[\mathbf{K}_{u}\right]$ is an initial displacement stiffness matrix, $\Delta \mathbf{u}$ is a vector of displacement increments and $\Delta \mathbf{F}$ is the external loading increment.

In the presented research, the stability problem is limited by linearised formulation of the lateral buckling, thus $\Delta \mathbf{F}=0$, when only small strains and finite rotations have to be considered, ie $\left[\mathbf{K}_{u}\right]=0$. It is assumed that the load state is described by external load vector $\mathbf{F}$ and a scalar load-intensity factor $\lambda_{c r}$. The second variation of the total potential energy provides a mathematical model of the stability problem expressed as well known in mathematics as eigenvalue problem:

$$
\left(\left[\mathbf{K}_{\text {lin }}\right]+\lambda_{c r}\left[\mathbf{K}_{g}\right]\right) \mathbf{r}_{c r}=\mathbf{0},
$$

where $\left[\mathbf{K}_{g}\right]$ is a geometric stiffness matrix, while $\lambda_{c r}$ is the stability load factor and $\mathbf{r}_{c r}$ is the vector of buckling mode shapes. The number of given values for the load factor and shape modes depend on the number of the equations, included in system (12). The most interesting research in civil engineering is the first value and corresponding shape mode, while other results are more important for theoretical analysis.

Warping is a particular mechanical phenomenon in the classical theory of thin-walled beams. It is a case of out-of plane cross-sectional deformation, which is expressed by geometrical function of cross-sectional sectors. In such a case, normal and tangential stresses in a cross-section are considered. A general parameter, which is expressed by the combination between these stresses, is a longitudinal bimoment. The widely used hypothesis of a plane cross-section is a special case of the Vlasov's hypothesis of sectors [7].

The tapered column has been simulated by using two kinds of finite elements (FE): one-dimensional for the column modelling as a bar and two-dimensional shell finite elements. Material of the thin-walled column has been considered as homogenic, isotropic as well as obeying the Hooke's law.

For numerical modelling of the axially loaded and bent column with a variable cross-section, one-dimensional FE described by 14 DOF [20] was applied (Fig 3). Each end of the FE is described by three linear displacements $u_{x}, u_{y}$ and $u_{z}$ in corresponding directions, two

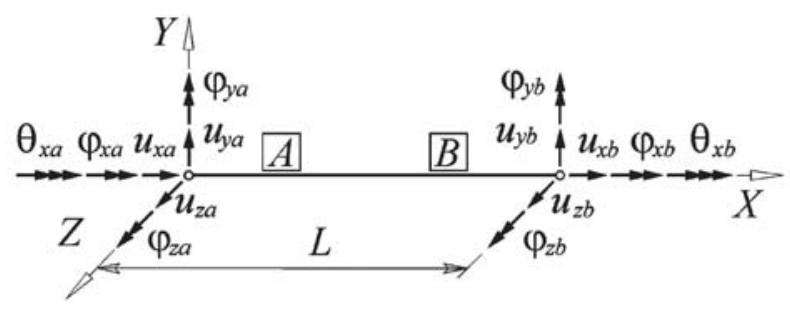

Fig 3. One-dimensional FE with warping and its DOF 
rotations $\varphi_{y}$ and $\varphi_{z}$ about the cross-sectional transversal axes, twisting $\varphi_{x}$ around the longitudinal axis and warping DOF $\theta_{x}$.

Using a standard FEM technique, the tapered column was simulated by the FE with warping, each of them was defined by a constant cross-section (Fig 4). The values of an external load $N_{f}$ and $M_{f}$ as well as boundary conditions of the column were defined by experimental results of a real industrial steel frame. At this stage of modelling a standard well-tested FEM package STAAD.Pro has been used.
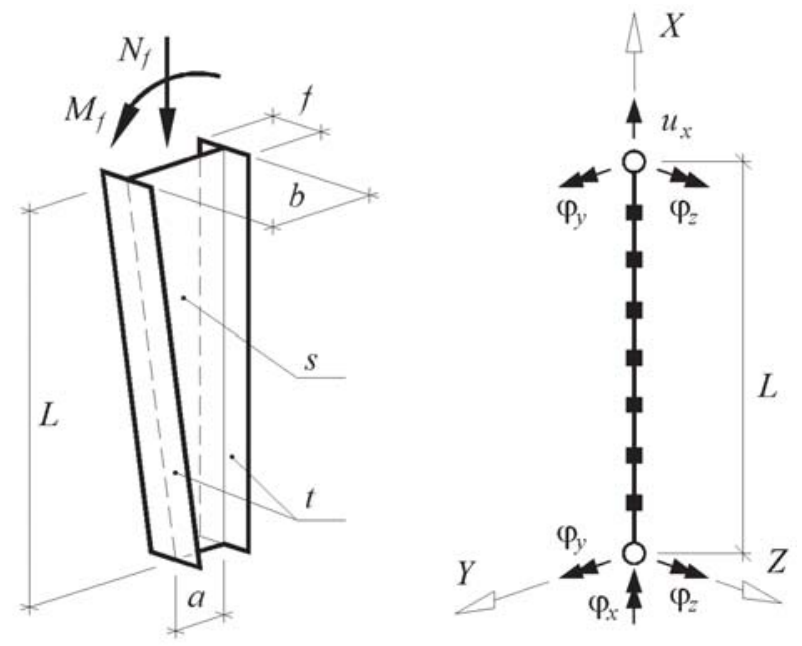

Fig 4. The tapered column: geometry (a) and FE model (b)

For a more "exact" modelling the typical triangle shell element from the code COSMOS/M was applied (Fig 5). These finite elements are defined by $18 \mathrm{DOF}$. Each node of such FE is described by three linear displacements $u_{x}, u_{y}$ and $u_{z}$ and three rotations $\varphi_{x}, \varphi_{y}$ and $\varphi_{z}$.

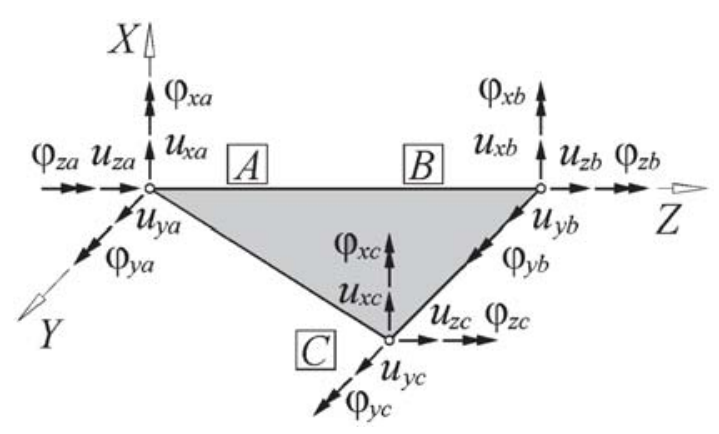

Fig 5. Shell FE with its DOF

The above-mentioned finite elements have been used for the static linear analysis of the whole industrial frame. Therefore, at the first stage of investigations an initial axial force and a bending moment as well as a combination of these factors were defined. Next, the linearised stability problem [12] was analysed by applying two-dimensional finite elements.

\subsection{Numerical solution of the axially loaded column}

There were carried out a large number of simulations within a wide range of variation of the second crosssectional moment of area [25]. First, the column has been loaded by a critical force $N_{c r y 2}$, solved as for a uniform member, using the geometrical characteristics of the bigger end "2". Second, by using an original programme COSMOS/M the correction factor $\alpha_{n}$ has been calculated. Next step - a critical force of tapered column is given by multiplying the critical axial force $N_{c r y 2}$ by the uniform column and the correction factor $\alpha_{n}$.

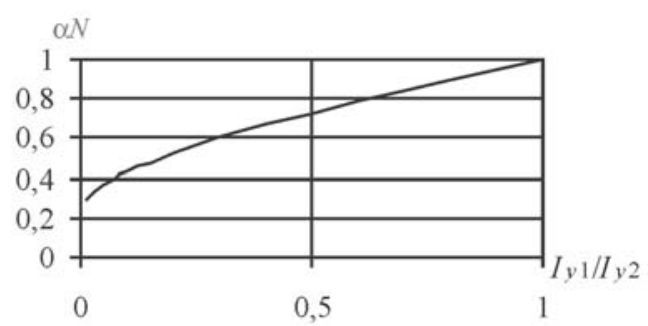

Fig 6. Function of the correction factor $\alpha_{n}$ depending on a relative second moment of the pinned column area

From these simulations many values of the correction factor $\alpha_{n}$ for the axially loaded pin-end column have been calculated (Fig 6). By using computer simulations there have been determined that values of correction factor $\alpha_{n}$ found for pin-ended column can be also used for other column support types.

\subsection{Beam subjected to pure bending}

When the column has been modelled by using an assumption that its cross-sections are subjected by bending moments only, end-sections "A" and "B" have been supported in the cross-sectional direction and one of the ends had the axial node, which cannot move in a longitudinal direction. Many of solutions with a wide range of the ratios of cross-sectional characteristics have been formed. At both ends the column has been subjected to the critical bending moment $M_{\text {cr } y 2}$ (Fig 7), given as for a uniform member by using the bigger end geometrical characteristics.

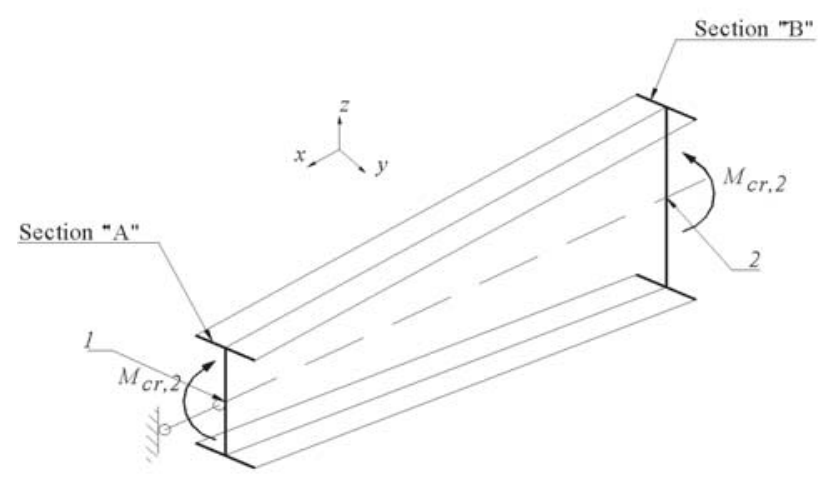

Fig 7. Geometry and external loading by two end-moments of the tapered column 


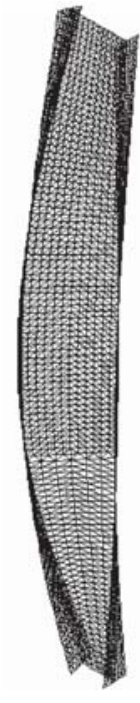

Fig 8. The first buckling shape mode of the tapered column, according to the solution by FEM code COSMOS/M

By using the FE programme COSMOS/M the values of a correction factor $\alpha_{m}$ have been calculated. Later a critical bending moment $M_{c r y 2}$ of a uniform member and the given correction factor $\alpha_{m}$ have been multiplied. Column lost stability in the lateral torsional manner (Fig 8).

From these simulations the correction factor $\alpha_{m}$ for pin-end member subjected to pure bending have been calculated (Fig 9). By computer simulation it has been found that values of factor $\alpha_{m}$, determined for pin-ended columns, can be also used for other types of column supports.

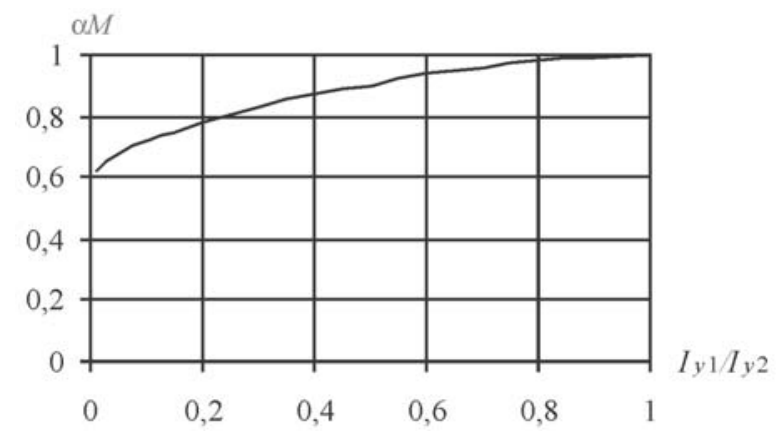

Fig 9. Function of the correction factor $\alpha_{m}$ depending on a relative second moment of the pinned column area

\section{Practical solution method}

For practical solution of such tapered beam-columns subjected to an axial force or bending moment it is more easy to use equivalent cross-sectional height $h_{t r}$, which may be obtained from the following equations: for the axially loaded tapered column

$$
\left(\frac{\pi}{\mu_{y} L}\right)^{2} E I_{t r}=\alpha_{n}\left(\frac{\pi}{\mu_{y} L}\right)^{2} E I_{y 2}
$$

for the tapered column, which is loaded by bending moment only

$$
E I_{z}\left(G I_{t t r}+\left(\frac{\pi}{\mu_{\omega} L}\right) E I_{\omega t r}\right)=\alpha_{m}^{2} E I_{z}\left(G I_{t}+\left(\frac{\pi}{\mu_{\omega} L}\right) E I_{\omega}\right)
$$

For a practical calculation such equivalent cross-sectional heights may be used (Table):

$$
\begin{aligned}
& h_{t r n}=\alpha_{n} \cdot h_{2} ; \\
& h_{t r m}=\alpha_{m} \cdot h_{2} .
\end{aligned}
$$

The values of the factors $\alpha_{n}$ and $\alpha_{m}$

\begin{tabular}{|c|c|c|c|c|c|c|}
\hline$I_{y 1} / I_{y 2}$ & 0,010 & 0,050 & 0,100 & 0,200 & 0,300 & 0,400 \\
\hline$\alpha_{n}$ & 0,563 & 0,629 & 0,676 & 0,740 & 0,788 & 0,829 \\
\hline \hline$I_{y 1} / I_{y 2}$ & 0,500 & 0,600 & 0,700 & 0,800 & 0,900 & 1,000 \\
\hline$\alpha_{n}$ & 0,864 & 0,895 & 0,924 & 0,951 & 0,976 & 1,000 \\
\hline \hline$I_{y 1} / I_{y 2}$ & 0,010 & 0,050 & 0,100 & 0,200 & 0,300 & 0,400 \\
\hline$\alpha_{m}$ & 0,561 & 0,633 & 0,684 & 0,755 & 0,814 & 0,857 \\
\hline \hline$I_{y 1} / I_{y 2}$ & 0,500 & 0,600 & 0,700 & 0,800 & 0,900 & 1,000 \\
\hline$\alpha_{m}$ & 0,891 & 0,933 & 0,957 & 0,979 & 0,990 & 1,000 \\
\hline
\end{tabular}

\section{Conclusions}

1. From an analysis of references concerning the investigation of resistance of single-span frames' steel tapered columns, the absence of satisfactorily spread and grounded methods of their practical design was determined.

2. From the numerical experiments with axially loaded tapered column, using the FEM, the correction factor $\alpha_{n}$ has been described and a critical force obtained. After the analysis of the results it has been determined that this factor, differently from the existing methods, depends only on the column ends second crosssectional moments of area, ie ratio $I_{y 1} / I_{y 2}$. Therefore, it is possible to use this factor as universal one for all types of column supports.

3. From the numerical experiments with the tapered column subjected to bending moment only, the correction factor $\alpha_{m}$ has been obtained. This factor depends only on second cross-sectional moments of area ratio $I_{y 1} / I_{y 2}$ in the column ends, too.

4. For practical engineering calculations the proposed algorithm and the usage of equivalent crosssectional heights $h_{t r, n}$ and $h_{t r, m}$ are recommended.

\section{References}

1. ENV 1993-1-1. Eurocode 3. Design of Steel Structures. Part 1.1: General Rules and Rules for Buildings. European Presstandard, 1992.

2. Šapalas, V.; Kvedaras, A.-K. Stability of axially loaded tapered columns. Statyba (Civil Engineering), Vol 6, No 3, 2000, p. 158-161 (in Lithuanian). 
3. Baptista, A. M.; Muzeau, J. P. Design of tapered compression members according to Eurocode 3. Journal of Constructional Steel Research, Vol 46, No 1-3, 1998, page of Internet No 121.

4. Tochaček, M. Design of struts with a variable cross-section. In: Stability of Steel Structures, Vol 1, 1995, p. 103-109.

5. Samofalov, M.; Kačianauskas R. Investigation of thinwalled column with variable $I$-section stability using finite element method. Statyba (Civil Engineering), Vol 6, No 2, 2000, p. 69-75 (in Lithuanian).

6. Timoshenko, S. P.; Gree J. Theory of Elastic Stability. New York: McGraw-Hill, 1961. 340 p.

7. Vlasov, V. Z. Thin-walled Elastic Beams. Jerusalem: Israel Program of Scientific Translation, 1961. 582 p.

8. Bleich, F. Buckling Strength of Metal Structures. New York: McGraw-Hill, 1952. 554 p.

9. Dinnik, A. N. Buckling. Torsion (Продольный изгиб. Кручение). Moscow: AN USSR, 1955. 451 p. (in Russian).

10. Friedman, Z.; Kosmatka, J. B. Exact stiffness matrix of a non-uniform beam. Part-II: Bending of a Timoshenko beam. Computers \& Structures, Vol 49, No 3, 1992, p. 545-555.

11. Braham, M. Some comments on elastic lateral buckling of prismatic doubly symmetric steel $I$-beams proposal for new formulas. Building Research Journal, Vol 44, No 4, 1996, p. 237-251.

12. Gendy, A. S.; Saleeb, A. F. On the finite element analysis of the spatial response of curved beams with arbitrary thinwalled section. Computers \& Structures, Vol 44, No 3, 1992, p. 639-652.

13. Bedair, O. K. A contribution to the stability of stiffened plates under uniform compression. Computers \& Structures, Vol 66, No 5, 1998, p. 535-570.

14. Schafer, B. W.; Peköz, T. Cold-formed steel members with multiple longitudinal intermediate stiffeners. Journal of Structural Engineering, Vol 124, No 10, 1998, p. 1175-1180.

15. Stephen, D. B.; Steven, G. P. Improving the eigenvalue using higher order elements without re-solving. Structural Engineering and Mechanics, Vol 5, No 4, 1997, p. 385-398.
16. Plank, R. J.; Wittrick, W. H. Buckling under combined loading of thin, flat-walled structures by a complex finite strip method. Numerical Methods in Engineering, Vol 8, 1974, p. 323-329.

17. Cheung, Y. K. Finite strip method in structural analysis. Oxford: Pergamon Press, 1976. 542 p.

18. Friberg, P. O. Beam element matrices derived from Vlasov's theory of open thin-walled elastic beams. International Journal for Numerical Methods in Engineering, Vol 21, 1985, p. 1205-1228.

19. Murray, N. W. Introduction to the theory of thin-walled structures. Oxford: University Press, 1984. 364 p.

20. Yang, Y.-B.; McGuire, W. Stiffness matrix for geometric nonlinear analysis. Journal of Structural Engineering, Vol 112, No 4, 1986, p. 853-877.

21. Batista, R. C.; Antinini, R. C.; Alves, R. V. An asymptotic modal approach to nonlinear structural elastic instability. Computers \& Structures, Vol 38, No 4, 1991, p. 475-484.

22. Mohamed, S. E.; Kounadis, A. N.; Simitses, G. J. Elasto-plastic analysis of gabled frames with nonprismatic geometry. Computers \& Structures, Vol 44, No 3, 1992, p. 693-697.

23. Pasquino, M.; Marotti de Sciarra, F. Buckling of thin-walled beams with open and generically variable section. Computers \& Structures, Vol 44, No 4, 1992, p. 843-849.

24. Yang, M. F.; Liang, C. C.; Chen, C. H. A rational shape design of externally pressured torispherical dome ends under buckling constraints. Computers \& Structures, Vol 43, No 2, 1992, p. 839-851.

25. Šapalas, V. Stress-strain analysis of single span frames with tapered members. Statyba (Civil Engineering), Vol 6, No 2, 2000, p. 82-86 (in Lithuanian).

26. Ronagha, H. R.; Bradfordb, M. A.; Attardb, M. M. Nonlinear analysis of thin-walled members of variable crosssection. Part II: Application. Computers \& Structures, Vol 77, 2000, p. 301-313.

27. Li, G.-Q.; Li, J.-J. A tapered Timoshenko-Euler beam element for analysis of steel portal frames. Journal of Constructional Steel Research, Vol 58, 2002, p. 1531-1544.

\section{LENKIAMŲ-GNIUŽDOMŲ KOLONŲ ANALIZĖ BAIGTINIŲ ELEMENTŲ METODU}

\section{V. Šapalas, M. Samofalov, V. Šaraškinas}

Santrauka

Teoriniais ir skaitiniais metodais analizuojamas trapecijos pavidalo kolonos, veikiamos lenkimo momento ir ašinès jègos, stabilumas. Konstrukcijos stabilumo analizei atlikti taikoma tipiné baigtinių elementų metodo programa COSMOS/M. Trapecinès kolonos kritinei jègai nustatyti siūloma tokia metodika, kai gerai žinomos bei plačiai taikomos pastovaus skerspjūvio strypų kritinès jègos reikšmès dauginamos iš specialiai gauto trapeciškumo korekcijos koeficiento $\alpha_{n}$. Analogiškai, pritaikius specialiai apskaičiuotą koeficientą $\alpha_{m}$, nustatoma trapecinès kolonos kritinio lenkimo momento reikšmè. Šiems koeficientams apibūdinti atliktas ịvairaus trapeciškumo kolonų skaitinis modeliavimas. Siūlomas uždavinio supaprastinimo būdas numato imti ekvivalentini skerspjūvio aukštị. Tokia metodika yra paranki inžinieriui praktikui.

Raktažodžiai: plonasienis strypas, erdvinis stabilumas, trapecinė kolona, baigtinių elementų metodas, deplanacija.

Vaidotas ŠAPALAS. Doctor, Assoc Professor at Dept of Steel and Timber Structures, Vilnius Gediminas Technical University, Vilnius, Lithuania. Research interests: computer modelling of steel structures, stability of tapered members.

Michail SAMOFALOV. Doctor, Assoc Professor at Dept of Strength of Materials, Vilnius Gediminas Technical University, Vilnius, Lithuania. Research interests: numerical computer methods, design of steel and concrete structures, inspection of real buildings.

Viačeslavas ŠARAŠKINAS. Doctor, Assoc Professor at Dept of Steel and Timber Structures, Vilnius Gediminas Technical University, Vilnius, Lithuania. Research interests: computer simulation of steel structures, composite steel-concrete structures, tubular steel-concrete members. 